\title{
Physico-Chemical Characteristics of a Fresh Water Pond of Ghugus, District Chandrapur, Maharashtra (India)
}

\author{
L. S. Durge ${ }^{*}$, A. A. Dhammani ${ }^{2}$, R. N. Chavhan ${ }^{3}$ \\ ${ }^{1}$ Department of Zoology, Dr.Ambedkar College of Arts,Commerce and Science, Chandrapur, (M.S.), India|Principal, \\ Gramgeeta, Mahavidyalaya, Chimur, (M.S.), India|Department of Zoology, Mahatma Gandhi College, Armori, (M.S.), India
}

*Corresponding Author email: lsdurge112@gmail.com Mob.+919403320631

Available online at: www.isroset.org

Received: 22/May/2018, Revised: 02/Jun/2018, Accepted: 17/Jun/2018, Online: 30/Jun/ 2018

\begin{abstract}
Water is the most necessary component for the living beings. Life on the earth is never possible without water. Water is one of the most vital elements for the human environments. It is being used for many purposes e.g. Industrial water supply, drinking, irrigation, propagation of fish and other aquatic systems and generation of hydro-power plants. Water is the main source of energy and governs the evolution on the earth. $71.9 \%$ of earth surface is covered with water (CIA, 2008), out of which, $96.5 \%$ of the world's water is sea water which is salty that is not to be directly useful for irrigation, drinking, domestic and industrial purposes.1.7\% is in groundwater and $1.7 \%$ in glaciers and the ice caps. Less than $1 \%$ water is present in ponds, lakes, rivers, dams, etc., which is used by human beings for drinking, industrial, domestic and agricultural purposes. According to an estimate about $70 \%$ of all the available water in our country is polluted due to the discharge of effluents from the industries, domestic waste, land and agricultural drainage (Shrivastava and Kanungo, 2013).

In the present study an attempt has been made on physico-chemical characteristics of a pond, located in Ghugus Town in Chandrapur district of Maharashtra. The study was carried out for a period of twelve months i.e. November 2014 to October 2015. Monthly details have been collected and were represented seasonally along with standard deviation. Different parameters were taken in the study were Humidity, Atmospheric and water temperature, $\mathrm{pH}$, Electrical Conductivity, Total Dissolved Solids, Dissolved oxygen, Biochemical Oxygen Demand, Total alkalinity, Bicarbonate Alkalinity, Total Hardness, Calcium Hardness, Chloride, Nitrate-Nitrogen and Phosphate. The results of the present study indicated that the water of the pond lies just below the level of eutrophication.
\end{abstract}

Keywords-- Physico-chemicals, Malgujari Talav, pollution, pH, TDS, DO, BOD

\section{INTRODUCTION}

Ponds are important wetlands located in and around human localities as they are generally semi natural ecosystems constructed by man in landscape suitable for water stagnation. Ecosystem services rendered by these wetlands are innumerable including tangible and non -tangible ones. Besides acting as a source of fresh water, they lower the ambient temperature, raise the water table, increase the diversity of flora and fauna, and provide aesthetic atmosphere.

Due to uncontrolled increase in human population and development of township at large, these freshwater bodies are under enormous pressure owing to their overuse on one hand and enrichment due to nutrients and organic matter on the other, leading to the cultural eutrophication. Erosion of catchment and direct pouring of domestic effluents along with sewage are threatening these wetlands all over the world. In view of the above, the present study deals with the assessment of physico-chemical characteristics of a freshwater pond located in the middle of township of Ghugus district Chandrapur of Maharashtra, India.

\section{RELATED WORK}

Pandey and Verma (2004) studied the influence of catchment on chemical and biological characteristics of Baghdara Lake and Udai Sagar Lake in Southern Rajasthan. The two lakes were of contrasting features with Baghdara Lake receiving runoff from undisturbed woodlands ad Udai Sagar lake receiving runoff from urbanized regions. The physicochemical and biological analysis of both the lakes reveals that Udai Sagar Lake was polluted and reaching eutrophic condition, whereas Baghdara Lake was unpolluted. The study also shows that the dredging of sediment containing phosphorus as a restoration measure for eutrophic lakes was effective. 
Siddiqi and Chandrashekhar (1996) reported the new distributional record of Trichotria tetratis and Daphnia lumholtzi from Kolleru lake Andhra pradesh. Trichotria tetratis occurred in waters of high conductivity $(130 \mathrm{mS} / \mathrm{m})$ and higher total alkalinity and total hardness. The

\section{MATERIALS AND METHODS}

\section{A. Study site characteristics:}

The pond selected under investigation is known as "Malgujari Talav". It is situated at the central part of the town Ghugus, Maharashtra. Ghugus town is well known for coal mines in and around the town. It is located at $19.9414^{\circ} \mathrm{N}$ latitude and $79.1153^{\circ} \mathrm{E}$ longitude. The Pond is somewhat circular in outline. Maximum depth of the pond at full water level is about $4.5 \mathrm{~m}$ and the average depth is about $2.5 \mathrm{~m}$. The surface area is about 11,000 sq.m

\section{B. Sampling and Sample Processing:}

Observations for of the present study were carried for a period of twelve months (November 2014 to October 2015). Observation and analysis were done every month. However, the results are expressed on seasonal basis as variation was of less magnitude. Since the climate of the region is tropical monsoonal, three clearly defined seasons were identified viz. rainy (July - October), winter (November - February) and summer (March - June). The sampling was done during morning hour (8:30 to 10:30 am) and the water samples were collected using modified Hal's sampler. Physico-chemical parameters like temperature, $\mathrm{pH}$, electrical conductivity, dissolved oxygen, total dissolved solids, nitrate nitrogen, phosphate were analyzed with the help of thermometers and Elico Water Quality Analyzer PE 138. Transparency was measured by Secchi disc. For analysis of other chemical parameters, the samples were collected in glass bottles and transported to laboratory and were analyzed as per procedure given by Adoni et al.(1985) and APHA (1998).

\section{RESULTS AND DISCUSSION}

Results of physico-chemical attributes of water and a few climatic parameters are presented in table 1 .

\section{Humidity:}

Maximum humidity was recorded during the month of August i.e. $69 \%$ and minimum in April i.e. $34 \%$. It is a typical trend in equatorial regions where hot and humid rainy season prevails.

\section{Atmospheric and Water Temperature:}

Temperature is a physical factor that alters the water characteristics and considered as an important factor in controlling the fluctuation of plantation and functioning of aquatic ecosystem. (Wetzel, 1975; Dwivedi and Pandey, 2002; Singh and Mathur, 2005). In the present investigation phosphorus and other heavy metal ion were also high in the region where the species had been recorded. Thus, Trichotria tetratis could be used as a pollution indicator for eutrophic conditions as the species had also been reported from sewage polluted tank.

seasonal variability of atmospheric and water temperature have been observed. It was maximum during summer and comparatively less during monsoon and minimum during winter. Kannan and Job (1980) also found similar results as observed in the present study.

Interestingly the magnitudes of variation in atmospheric and water temperatures were of less during summer. Surface temperature closely reflected to ambient air temperature. This is particularly true for shallow lakes and ponds like in presents study (Efford, 1967; Moss, 1969). It may probably due to smaller water bodies. It is now a well-known fact that smaller the body of water, more quickly it reacts with the changes in the atmospheric temperature (Welch, 1952; Ghosh and Basu, 1968; Young, 1975; Sehgal, 1980; Jayanti, 1994; Joshi and Singh, 2001).

\section{pH:}

Welch (1952) states that the limnological value of $\mathrm{pH}$ is a limiting factor and works as an index of general environmental condition. The $\mathrm{pH}$ value of the pond showed alkaline tendency with a few variations. The maximum $\mathrm{pH}$ value were in the month of April i.e. 9.26 and minimum in the month of October i.e. 8.99. It is evident from the data that the $\mathrm{pH}$ declines during the rainy season and increases during summers. Sharma et al., (1984) states that in India, many small confined water pockets are particularly alkaline in nature.

Seasonal fluctuations are small indicating good buffering capacity. It has been suggested that the high $\mathrm{pH}$ is normally associated with a high photosynthetic activity in water (Goel et al., 1986; Wani and Subla, 1990). High value also promotes the growth of algae and results heavy bloom of phytoplankton (George, 1962; Nandan and Patel, 1992).

\section{Electrical Conductivity:}

Electrical conductivity of the water depends on the nature and concentration of salts. In the present study high values of conductivity, could be due to high ionic concentration, pollution status, trophic levels, some domestic effluents and other organic matter in water (Ahluwalia, 1999; Fokmare and Musaddique, 2001). The range of electrical conductivity in the present study was between $2.22 \mathrm{mScm}-1$ and $2.61 \mathrm{mScm}-$ 1. The values of electrical conductivity showed marked seasonal variation being maximum during rainy season and minimum during winter season. Similar results were observed by various workers (Datta and Bhagwati, 2007; Hulyal and Kaliwal, 2011; Ramulu and Benarjee, 2013). The water during the summer decreases as a result of high temperature and evaporation.

\section{Total dissolved solids:}


As water is a universal solvent it has a large number of salts dissolved in it which largely governs the physico-chemical properties of water. The maximum value of total dissolved solids were recorded in July (1356.50 mgl-1) and minimum were recorded in January (889.50 mgl-1). A seasonal variation shows maximum values in summer followed by rainy season and minimum during the winter season. The high value of TDS during rainy season may be due to addition of domestic sewage along with waste waters, garbage etc. in

\section{Dissolved Oxygen:}

Oxygen content is important for direct needs of many organisms and affects the solubility of many nutrients and therefore the periodicity of aquatic ecosystem (Wetzel, 1983). Fritsch (1907) stated that the oxygen contents in tropical water would be low considering their high temperature. The results in the present study shows that highest value of dissolved oxygen was recorded during the month of January i.e. $9.98 \mathrm{mgl}-1$ and least in the month of June i.e. $6.01 \mathrm{mgl}-1$. The value increased from July to January and then decreased from February to June. Results of the present study are similar to those reported by other (Prasad et al., 1985; Hulyal and Kaliwal, 2011; Ramulu and Benarjee, 2013).

\section{Biochemical Oxygen Demand:}

BOD is dissolved oxygen required by microorganism for aerobic decomposition of organic matter present in water. Jain and Dhamija (2000) have considered BOD as an important parameter in aquatic ecosystem to establish the status of pollution. The observation of present study shows that highest value of BOD (3.16 mgl-1) during the June and lowest (1.69 mgl-1) in January. Seasonally, the BOD was highest during late summer or in early rainy season. High BOD during late summer or in early rainy season is due to the presence of several microbes in water body which accelerates their metabolic activity with the increase in concentration of organic matter in the form of village and domestic wastes pouring into the pond with water run off (Kaushik and Saksena, 1999). Prasanna Kumari et al., (2003) stated that the higher values of BOD during rainy season was due to input of organic wastes and enhanced bacterial activity. High temperatures play an important role by increasing rate of oxidation.

The BOD of unpolluted water is less than $1.00 \mathrm{mgl}-1$ moderately polluted water 2.00-9.00 mgl-1 while heavily polluted water have BOD more than $10.00 \mathrm{mgl}-1$ (Adakola, 2000). In the present study, BOD is fluctuated between 1.55 and $3.26 \mathrm{mgl}-1$ in different seasons indicates that the pond is moderately polluted.

\section{Total Alkalinity:}

Alkalinity in most natural water is the function of bicarbonate and carbonates. Their salts get hydrolyzed in solution and produced hydroxyl ion. It is also used as a measure of productivity (Jhingran, 1982; Hulyal and Kaliwal, 2011). Natural water bodies in tropics usually show wide range of the natural surface of water body (Verma et al., 2012). Increased high concentration of TDS increases the nutrients of water body which was resulted into eutrophication of ponds (Swarnlata and Narsigharao, 1998; Singh and Mathur, 2005). The water containing more than $500 \mathrm{mgl}-1$ of TDS is not used for potable purposes. Hence, 500mgl-1 is desirable limit and 1500 mgl-1 maximum possible limit for domestic use (ICMR, 1975).

fluctuations in their total alkalinity value depending upon the geography and season.

In the present study the total alkalinity ranged between 428.25 to $578.01 \mathrm{mgl}-1$. It is gradually decreased from July to September and then increased in the month of October reaching to $556.90 \mathrm{mgl}-1$ again followed by a decrease in November and December. Seasonally highest value was recorded during rainy and lowest during the summer season. Increases in total alkalinity during rainy season were due to input of water and dissolution of calcium carbonate ion in value of calcium during winter season. The decrease in the amount of calcium may be due to its absorption by living organism. Hulyal and Kaliwal (2011) found that the calcium content was higher in summer and lower in monsoon season. However, Verma et al., (2012) observed maximum calcium content in the water of Chandlodia Lake during monsoon and minimum during winter.

Goldman and Horne (1983) reported that any value above 25 mgl-1 indicate calcium rich water. Higher calcium content in drinking water cause incrustation in water supply structure and adversely effect on domestic used (Raghvendra, 1992). The values of present study are found to desirable limit for the domestic use.

\section{Chloride:}

In the present study chloride content ranged between 77.40 mgl-1 to $126.62 \mathrm{mgl}-1$. Variations in chloride content were irregular as they declined from July to September (126.62 to $74.40 \mathrm{mgl}-1)$ and then increased in October and again gradually decreased from November reached to $81.10 \mathrm{mgl}-1$ during January. The chloride content showed marked seasonal variation being maximum during rainy and minimum during winter season, which is the agreement with the observation made by Saha and Pandit, (1985) and Hulyal and Kaliwal, (2011). However, higher concentration of chloride during the summer and lower during the winter was also reported (Sharma et al., 2007; Verma et al., 2012; Ramulu and Benarjee, 2013). Higher concentration of chloride content was found during the rainy season may be attributed to increasing the organic waste of human origin with runoff water. Munawar (1970) suggested that higher value of chloride in water as an index of pollution of animal origin. Higher concentration also is associated with frequently runoff loaded with contaminated water from surrounding (June and Fred, 1987; Sunder, 1988). 


\section{Nitrate- Nitrogen:}

Nitrates are contributed to fresh water through discharge of sewage, industrial wastes and runoff from agricultural fields. The concentration and rate of supply of nitrate in the land use practices of the surrounding watershed. Results of the present study envisaged that the value of NO3-N varied from 0.71 mgl-1 to $3.17 \mathrm{mgl}-1$. Lower values were recorded during rainy season and higher values were found during summer season. Higher concentrations are due to influx nitrogen rich flood water and bring about large amount of sewage. The rainy season was period with the highest nitrate-nitrogen concentration which is known to support the formation of blooms (Shai and Sinha, 1969; Anderson, et al., 1998).

\section{Phosphate:}

Phosphate is the key nutrient also causing eutrophication leading to extensive algal growth. The results of present study showed that maximum phosphate concentration observed in the month of August i.e. $0.063 \mathrm{mgl}-1$ and minimum in January i.e. $0.028 \mathrm{mgl}-1$. It is evident from the data that seasonally phosphate concentration in the pond was more in summer followed by rainy followed by a decline in winter season. Highest seasonal values were reported during rainy season and lowest during winter season is in the vicinity with the findings of various workers (Kaur et al., 1997; Khurshid et al., 1997; Hulyal and Kaliwal 2011; Verma et al., 2012).

The increase in the concentration of phosphate during rainy season is the results of incoming water from the catchment areas of human settlements and the entry of domestic sewage. The occurrence of fewer nutrients during winter season may be due to their utilization in macrophytic growth. Increase in nutrients during summer season is related with the decrease in water level effecting concentration and the release of nutrient during decomposition, which increases with rise in temperature (Chaurasia and Adoni, 1985).

Comparatively higher values of total alkalinity may be attributed to the hardness. Philipose (1960) has classified freshwater ponds of India into four categories on the basis of alkalinity. Ponds receiving effluents have been reported to show alkalinity from 462 to $505 \mathrm{mgl}^{-1}$. He further endorsed that polluted ponds may have even higher alkalinity. In another study Prasad et al. (1985) had given a range of alkalinity from 128 to $730 \mathrm{mgl}^{-1}$. Similarly Kumari et al. (2007) obtained remarkable differences in the total alkalinity in different months $\left(140-370 \mathrm{mgl}^{-1}\right)$ in two tropical ponds of India. They have further correlated the higher $\mathrm{pH}$ values with alkalinity.

A higher level of chlorides in the present investigation is unusual. However even greater concentrations of chlorides have been reported by Chowdhury and Mamun (2006). Munawar (1970) suggested that higher chlorides in water are an index of pollution of animal origin. It has also been observed during the present investigation that the pond under observation has been under constant pressure of animal bathing, receives a variety of effluents from village discharge, as well as organic and inorganic wastes from a temple nearby the water body.

\section{CONCLUSION AND FUTURE SCOPE}

Present study provides a base line data for the conservation and monitoring of the pond. Data envisaged that the current status of the pond lies just below the levels of eutrophication. The present findings highlight the toxicity of tannery effluents and its component, chromium exposed to fish and fish food organisms with their diverse nature during their acute and chronic exposure. Acute toxicity studies are among the first steps in determining the water quality requirements of fish and fish food organisms which could allow a sensitive approach to predict the potential risk of persistent contaminants like heavy metals or in their ecological risk assessment, which is helpful in formulating the $\square$ safe levels $\square$ of such contaminants. The values of the present study may provide useful data to set up national and local water quality criteria (WQC) for various heavy metals and fly ash. Further, this study may take crucial role in the determination of the safe disposal level of them. A few efforts like diversion of sewage, presentation of leaching of nutrients from catchment area through plantations would definitely yield good results.

So, further studies on pond water pollution are required to a frame work for prevention of discharge of domestic sewage and crude pollutants from different industries situated around it. Appropriate authorities both Government and nongovernment organizations should come forward to prevent the water bodies from different pollution load to conserve its biodiversity and sustainable development through diversified farming system with the involvement of local people resulting socio-economic upliftment.

Table 1: Seasonal variation in physico-chemical characteristics of water of Malgujari talav from November 2014 to October 2015.

\begin{tabular}{|c|l|l|l|l|}
\hline $\begin{array}{l}\text { Sr. } \\
\text { No. }\end{array}$ & Parameters & \multicolumn{3}{|c|}{ Seasons } \\
\hline & & \multicolumn{1}{|c|}{ Rainy } & \multicolumn{1}{|c|}{ Winter } & Summer \\
\hline & & $\begin{array}{c}\text { July- } \\
\text { October }\end{array}$ & $\begin{array}{c}\text { November- } \\
\text { February }\end{array}$ & $\begin{array}{c}\text { March- } \\
\text { June }\end{array}$ \\
\hline 1 & Humidity (\%) & $\begin{array}{l}69.75 \pm 8.2 \\
6\end{array}$ & $41.75 \pm 4.11$ & $34.50 \pm 12.79$ \\
\hline 2 & $\begin{array}{l}\text { Atmospheric } \\
\text { Temperature } \\
\left({ }^{\circ} \mathrm{C}\right)\end{array}$ & $\begin{array}{l}38.91 \pm 2.4 \\
4\end{array}$ & $28.02 \pm 2.55$ & $42.52 \pm 4.52$ \\
\hline 3 & $\begin{array}{l}\text { Water } \\
\text { Temperature } \\
\left({ }^{\circ} \mathrm{C}\right)\end{array}$ & $\begin{array}{l}34.03 \pm 2.1 \\
9\end{array}$ & $22.11 \pm 2.86$ & $33.25 \pm 4.63$ \\
\hline 4 & ${ }^{\mathrm{PH}}$ & $8.99 \pm 0.12$ & $9.02 \pm 0.14$ & $9.26 \pm 0.14$ \\
\hline 5 & $\begin{array}{l}\text { Electrical } \\
\text { Conductivity } \\
(\mathrm{mScm}-1)\end{array}$ & $2.61 \pm 0.41$ & $2.22 \pm 0.09$ & $2.44 \pm 0.07$ \\
\hline 6 & $\left.\begin{array}{l}\text { Total } \\
\text { Dissolved } \\
\text { Solids(mgl }\end{array}{ }^{-1}\right)$ & $1248.81 \pm$ & $1011.69 \pm 142$. & $1382.75 \pm 86.8$ \\
& 133.17 & 8 & 0 \\
\hline
\end{tabular}




\begin{tabular}{|c|c|c|c|c|}
\hline 7 & $\begin{array}{l}\text { Dissolved } \\
\text { Oxygen (mgl } \\
\left.{ }^{1}\right)\end{array}$ & $7.40 \pm 0.36$ & $9.29 \pm 0.91$ & $6.71 \pm 1.17$ \\
\hline 8 & $\begin{array}{l}\text { Biochemical } \\
\text { Oxygen } \\
\text { Demand (mgl } \\
\left.{ }^{1}\right)\end{array}$ & $2.79 \pm 0.22$ & $2.18 \pm 0.60$ & $2.78 \pm 0.45$ \\
\hline 9 & $\begin{array}{l}\text { Total } \\
\text { Alkalinity(mgl } \\
\left.{ }^{-1}\right)\end{array}$ & $\begin{array}{l}558.31 \pm 1 \\
9.99\end{array}$ & $464.24 \pm 25.55$ & $433.90 \pm 34.82$ \\
\hline 10 & $\begin{array}{l}\text { Bicarbonate } \\
\text { Alkalinity } \\
\left(\mathrm{mgl}^{-1}\right)\end{array}$ & $\begin{array}{l}462.39 \pm 1 \\
5.78\end{array}$ & $330.57 \pm 18.97$ & $331.26 \pm 50.10$ \\
\hline 11 & $\begin{array}{l}\text { Total } \\
\text { Hardness } \\
\left(\mathrm{mgl}^{-1}\right)\end{array}$ & $\begin{array}{l}242.96 \pm 1 \\
2.05\end{array}$ & $268.64 \pm 13.07$ & $271.62 \pm 12.38$ \\
\hline 12 & $\begin{array}{l}\text { Calcium } \\
\text { Hardness } \\
\left(\mathrm{mgl}^{-1}\right)\end{array}$ & $\begin{array}{l}43.16 \pm 8.6 \\
0\end{array}$ & $49.07 \pm 6.62$ & $41.32 \pm 6.87$ \\
\hline 13 & $\begin{array}{l}\text { Chlorides } \\
\left(\mathrm{mgl}^{-1}\right)\end{array}$ & $\begin{array}{l}95.63 \pm 26 . \\
88\end{array}$ & $81.93 \pm 3.54$ & $101.84 \pm 5.71$ \\
\hline 14 & $\begin{array}{l}\text { Nitrate- } \\
\text { Nitrogen }\left(\mathrm{mgl}^{-}\right. \\
\left.{ }^{1}\right)\end{array}$ & $0.86 \pm 0.27$ & $1.39 \pm 0.45$ & $2.64 \pm 0.53$ \\
\hline 15 & $\begin{array}{l}\text { Phosphate } \\
\left(\mathrm{mgl}^{-1}\right)\end{array}$ & $\begin{array}{l}0.05 \pm 0.01 \\
4\end{array}$ & $0.034 \pm 0.014$ & $0.046 \pm 0.009$ \\
\hline
\end{tabular}

Values are mean \pm standard deviation.

\section{REFERENCES}

[1] J. A. Adakole, "The effects of domestic, agricultural and industrial effluents on the water quality and biota of Bindare stream,

Zaria-Nigeria", , Department Of Biological Sciences, Ahmadu Bello University, Zaria, Nigeria, pp. 256, 2000. Phd Thesis

[2] A. D. Adoni, "Studies on microbiology of Sagar lake", , Sagar University,Sagar,India, pp. 216 1975. Ph.D. Thesis

[3] A. D. Adoni, G. Joshi, K. Gosh, S. K. Chaurasia, A. K. Vashya, Manoj Yadav and H. G. Verma, Work book on limnology", Pratibha Publishers C-10, Gour Nagar, Sagar-470003, India. 1985.

[4] A. A. Ahluwalia, "Limnological Study of wetlands under Sardar Sarovar command area",Gujarat University, Ahmedabad, 1999.Doctoral Dissertation

[5] D. M. Anderson, A. D. Cembella. and G. M. Hallegraeff, "Physiological Ecology of Harmful algal blooms", (Berlin: Springer- Verlag,), 1st Edn, pp. 647-648,1998

[6] K. K. Ansari, and s. Prakash , "Limnolocial studies on Tulsidas Tal of Tarai region of Balrampur in relation to fisheries", Poll. Res. 19(4), pp. 651-655, 2000

[7] APHA, "Standard Methods for the Examination of water and wastewater", American PublicHealth Association, Washington D. C., pp. 1000, 1998

[8] G. S. Carter, "Tropical climates and Biology, Nature (Lond)" Vol. $187, \mathrm{p} .843,1960$

[9] M. Chaurasia, and G.C. Pandey, "Study of physic- Chemical characteristic of some water pond of Ayodhya-Faizabad" Indian J. of
Environmental protection, Vol. 27, Issue. 11, pp.1019-1023, 2007.

[10] S. K. Chourasia, and A. D. Adoni, “Zooplankton dynamics in a shallow Eutrophic lake".Proc. Nat. Symp.Pure Appl. Limnology Bot. Soc. Sagar, Vol.32, pp. 30- 39, 1985

[11] A. H. Chowdhury, and A. A.Mamun, "Physio-chemical conditions and plankton population of two Fish ponds in Khulna” ,Univ. j.zool. Rajshahi Univ. Vol. 25, pp. 41-44. 2006.

[12] O. K. Dutta, and S. K. Bhagawati, (); "Limnology of Ox-bow Lake of Assam”,NSL, pp. 3-7, 2007.

[13] R. Bahekar , Y.There, "Seasonal variation in physico-chemical characteristics of Koradi Lake,District Nagpur", India. Indian Streams Research Journal, Vol.3, Issue. 2, pp.1-5, 2013

[14] S. M. Banerjea, "Water quality and soil condition of fish ponds in states of India in relation to fish Production", Indian journal of Fisheries, Vol. 14, Issue.2, pp. 115-144, 1967

[15] P.Choudhary, N. K.Dhakad, R. Jain, "Studies on the PhysicoChemical Parameters of Bilawali Tank,Indore (M.P.) India". IOSR Journal of Environmental Science, Toxicology and Food Technology (IOSRJESTFT), Vol. 8, Issue. 1, pp. 37-40, 2014.

[16] S. K. Shrivastava,V. K.Kanungo, "Physico- Chemical Analysis of Pond Water of Surguja District,Chhattishgarh, India". International Journal of Herbal Medicine, Vol.1, Issue.4, pp. 35-43, 2013.

[17] S. Umavathi,K. Longakumar, P. Subhashini."Studies on the nutrient content of Sulur pond in Coimbator,Tamil Nadu", Journal of Ecology and Environmental Conservation, Vol.13,Issue.5, pp. 501-504, 2007

[18] B. K. Dwivedi and G. C.Pandey, Physicochemical factors and algal diversity of two ponds in Faizabad, India, Vol. 21, Issue 3, pp. 361-370, 2002

[19] P. N. Goel, A. Y. Khatavkar, A. Y. Kulkarni and Trivedy R. K. (1986); "Limnological studies of a few freshwater bodies in southwestern Maharasthra with special reference to their chemistry and pollution", Vol, 5, No.2, pp. 79-84, 1986

[20] S. Khurshid, Zaheeruddin and A. Basheer,); "Pollution assessment and water quality status in parts of Cochin", I.J.E.P, Vol. 18, No.4, pp. 246- 249. 1997

\section{Author's Profile}

Mr. L.S. Durge completed his B.Sc.from St. Francis De'Sales College, Seminary Hills, Nagpur in 1984, and M.Sc. in 1986 with the specialization Fresh Water Zoology from institute of science, Nagpur, both the degrees from Nagpur University, Nagpur (M.S.) India. He worked as a Lecturer in Zoology at R.D. Science College, Aheri, Nabira

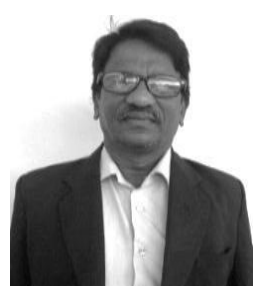

Mahavidyalaya, Katol and Javahar Lal Nehru Science College, Saoner. At present he is working as an Associate Prof. with an experience of 25 years to U.G. and 15 years to P.G. classes at Dr. Ambedkar College of arts, Commerce and science, Chandrapur (M.S.), India. $\mathrm{He}$ is also engaged in social activities like participation in blood donation camps, awaring the people about family planning, etc.Currently he is doing Ph.D. from Gondwana University, Gadchiroli (M.S.), India. His area of research is PhysicoChemical Characteristics of a Fresh Water Pond of Ghugus, District Chandrapur, Maharashtra (India). 
Mr. Amir A. Dhammani completed his B. Sc. from Nevajabai Hitkarini College Bramhapuri in 1982 and then M. Sc. in 1984 from Institute of Science, Nagpur. He obtained Ph. D.in 1985 and joined Nevajabai Hitkarini College, Bramhapuri in 1986. Under his able guidance 2 students have obtained $\mathrm{Ph}$. D. degree. He published 14 National and 21 International papers in different journals. At present he is working as a principal since 2016 .

Mr. R. N. Chavhan completyed his B.Sc. in 1993 from Amaravati University and M.Sc. from the same University in 1996.he is awarded with Ph. D. Degree by R.T.M. Nagpur University in 2012. His topic of research was, "Limnological studies in respect to physic-chemical and biological

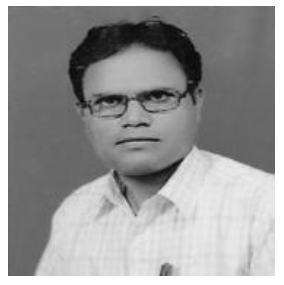
characteristics of Ramsagar Lake, Armori,dist- Gadchiroli (M.S.) India"

He worked on a U.G.C. sponsored minor research project entitled "Hydrological studies of some lentic ecosystems from Gadchiroli district of Maharastra state, India with respect to vertebrate fauna and Macro invertebrate species diversity" Sanctioned letter reference no.- F.No.47-1742/10 (WRO) Date:-25/5/2011. Total Sanctioned amount Rs.80000/-

At present he is working as an Assistant Prof. at Mahatma Gandhi Arts, Science and late N.P.Commerce College, Armori, District-Gadchiroli 44120 (M.S.) Indiasince2000. He is registered as $\mathrm{Ph}$. D. Superwiser at Gondwana University, Gadchiroliin 2013. He published 07 National and 10 International papers in different journals till now. He participated 35 Conferences, seminars and Work-shops with 15 abstracts, 3 posters and 17 oral presentations. 